\begin{tabular}{|l|c|c|}
\hline \multicolumn{2}{|c|}{ DJS Vol. 38 (2017) 248- 260 } \\
\hline 1969 & Delta Journal of Science & \\
\hline Research Article & Available online at & GEOLOGY \\
\hline
\end{tabular}

\title{
Petrophysical Evaluation and Pressure Analysis of the Cretaceous Alam EL-Bueib Sand Reservoirs, Jade Field, North Western Desert, Egypt
}

\author{
Waleed Afify*, Moataz Kh. Barakat**, Nader H. Elgindy**, and Mohamed A. Elbastawesy*. \\ * Khalda Petroleum Company, New Maadi, P.O Box 560, Maadi, Cairo, Egypt. \\ **Geology Department, Faculty of Science, Tanta University, Tanta 3157, Egypt.
}

moatazbarakat@science.tanta.edu.eg

\begin{abstract}
The present study deals with integration between petrophysical evaluation and reservoir pressure analysis to evaluate the hydrocarbon bearing sand zones of Jade field in north Western Desert, Egypt. Eight wells scattered in Jade field are analyzed and studied for determining the different petrophysical parameters of the Lower Cretaceous Alam ELBueib reservoirs. This study reveals the presence of three hydrocarbon-bearing sand zones (Alam EL-Bueib-3D, Alam ELBueib-3E and Alam EL-Bueib-3G) with good hydrocarbon potential encountered at different depth levels in the Alam ELBueib Formation. The well log analysis of the Alam EL-Bueib reservoirs including; data editing, data correction, and determination of lithology and porosity using different types of cross plots such as density-neutron and M-N cross plots. The density-neutron cross plots show that the Alam EL-Bueib reservoirs are mainly sandstones with some calcareous cement. The bulk density ranges from 2.3 to $2.6 \mathrm{~g} / \mathrm{cc}$. The effective porosities are $11.5,14.2$ and $11.05 \%$, and the shale volumes are 10.6, 5 and $5.9 \%$ in the Alam EL-Bueib-3D, 3E and 3G, respectively, implying good reservoir quality. Petrophysical parameters of the Alam EL-Bueib reservoirs are illustrated on iso-parametric maps to delineate the most effective sand zones. The iso-parametric maps of the Alam EL-Bueib reservoirs such as net pay, effective porosity and gross sand show an increase in the central southern and northern parts of the study area especially in Alam EL-Bueib-3D and $3 \mathrm{G}$ units, while in Alam EL-Bueib 3E unit shows an increase in the central southern part only. The analysis of reservoir pressure data is concerned mainly to locate the different fluid contacts and determine the pressure gradients of oil and gas-bearing zones. It gives necessary knowledge about the driving mechanisms that control the behavior of fluids within reservoirs.
\end{abstract}

Key words: Petrophysical Evaluation, Pressure Analysis, Jade Field, North Western Desert.

\section{Introduction:}

The Western Desert has numerous oil potentialities and may soon jump as a great oil and gas province. Jade field lies in the northern part of the Western Desert. It lies at $60 \mathrm{~km}$ from Matruh city and belongs to Matruh basin. The main producing horizons in Jade field are the Early Cretaceous reservoirs.

The work includes the following principle steps: 1) Determination of reservoir porosity and lithology using different types of crossplots, 2) Identification of different reservoir parameters characterizing the pay zones from well $\log$ data to spot light the promising locations for other further exploration, 3) Construction of iso- parametric maps to delineate the most effective sand zones, 4) Determination of the fluid types and contacts as well as the fluid characteristics of the hydrocarbon bearing zones, and finally 5) Comparison and integration of the petrophysical evaluation and pressure data in order to study the production potential of the Alam El-Bueib-3D, Alam El-Bueib-3E and Alam ElBueib-3G reservoirs in Jade field, Western Desert, Egypt. The study area is located in the Matruh basin and lie between latitudes $30^{\circ} 54^{\prime} 45^{\prime \prime}-30^{\circ} 57^{\prime} 45^{\prime \prime} \mathrm{N}$ and longitudes $27^{\circ} 05^{\prime}-27^{\circ} 09^{\prime} 45^{\prime \prime} \mathrm{E}$ (Fig. 1). 
The structural setting of the northern Western Desert has been discussed by many authors such as (Shata, 1953; Shukri, 1954; Sigaev, 1959; Amin, 1961; Said, 1962; Kostandi, 1963; El-Khadragy and Sharaf, 1994; Shalaby et al., 2000; Zein El-Din et al., 2001; ElKhadragy et al., 2010) and others. The most predominant structures in the northern Western Desert are the NE to ENE folding trend associated with reverse faulting. Most of those faults originated during Late Cretaceous to Early Tertiary time while the E-W faults exhibit evidence of strike-slip movements along the old existing faults (Sultan and Abd El-Halim, 1988).

The generalized stratigraphic column of the northern Western Desert (Fig. 2) includes most of the sedimentary succession from Pre-Cambrian basement complex to Miocene (Schlumberger, 1984 and 1995). The Alam El-Bueib Formation has a huge thickness in general that is predominantly white to yellow sandstones with siltstones and subordinate gray shales (Matruh Shale). Thin carbonate beds (limestones and dolomites) occur in most areas. Carbonates generally become more common towards the top, where the dolomite and oolitic limestone sequences thicken to the northwest (RRI report, 1982).

The Alam El-Bueib Formation ranges in age from Barremian to Aptian with at least one time gap identified within this unit. The paleoenvironment of deposition was shallow marine with more continental influence toward the south (Hantar, 1990). The Alam El-Bueib Formation becomes one of the most productive formations in the Western Desert. A wide spread unconformity has been recorded between the Jurassic and Cretaceous owing to local uplift, particularly in the northeast. The Early Cretaceous transgression covered a surface of considerable relief that caused wide thickness variations of lower most succession (El Gezeery et al., 1972).

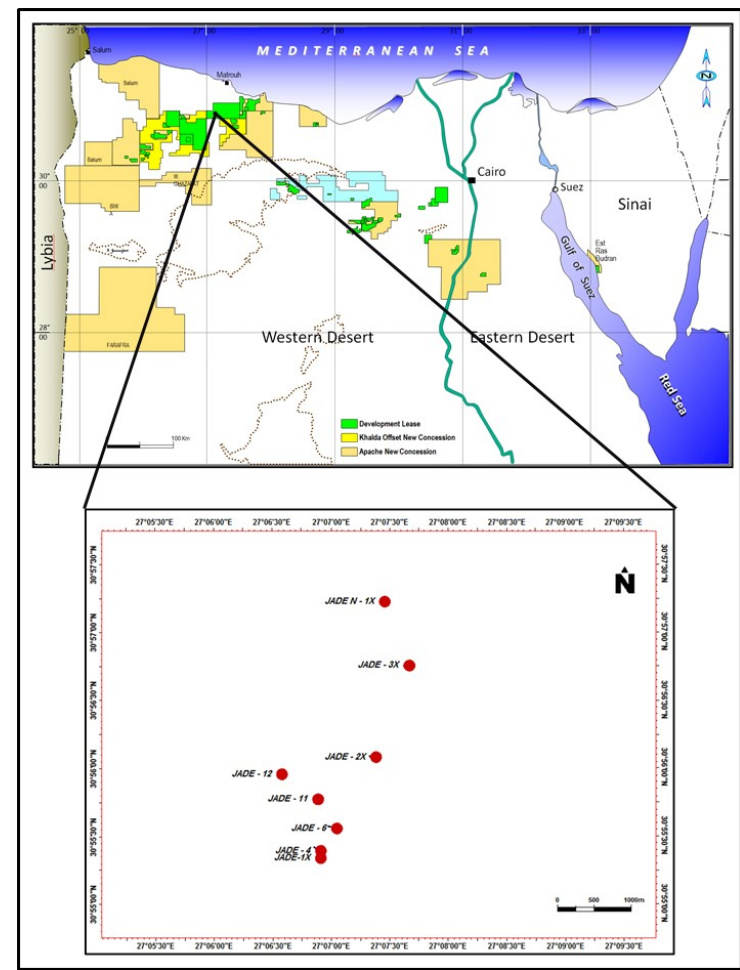

Figure (1): Base map of the drilled wells in Jade field.

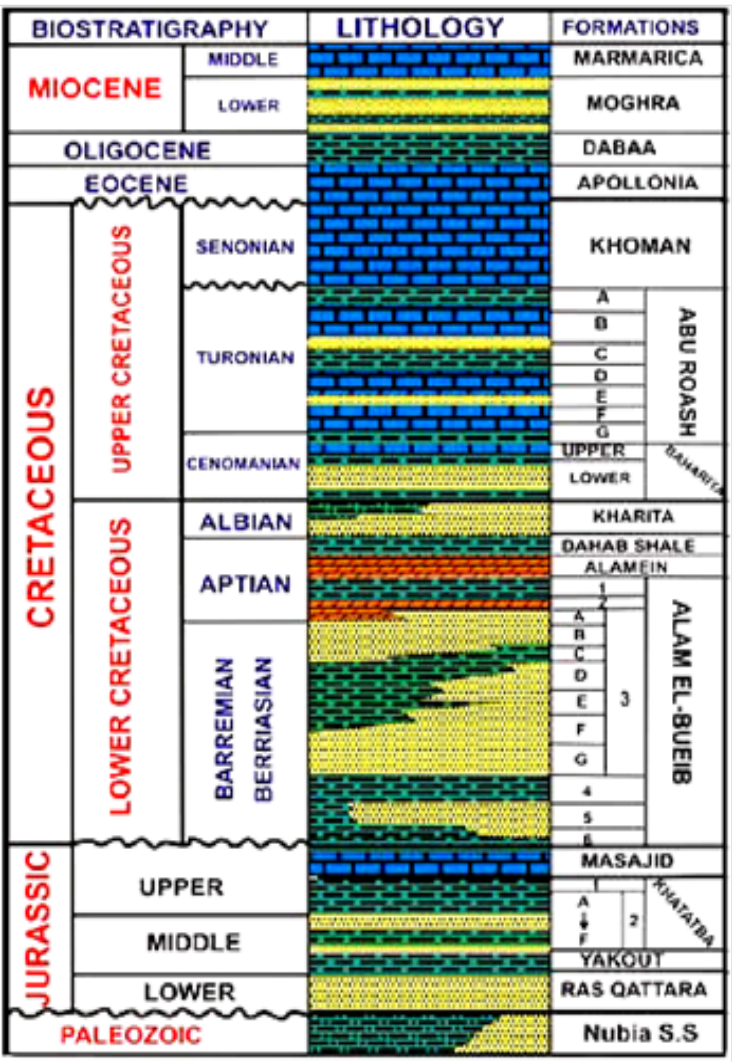

Figure (2): Generalized stratigraphic column of the north Western Desert (Schlumberger, 1984 and 1995).

Materials and Methods: 
The studied wells are: JADE-1X, JADE-2X, JADE3X, JADE-4, JADE-6, JADE-11, JADE-12 and JADE $\mathrm{N}-1 \mathrm{X}$. The available well logs are density, neutron, gamma ray, resistivity, caliper, and sonic beside pressure data, courtesy of Khalda Petroleum Company.

\section{A. Determination of lithology and porosity from crossplots}

The interpretation of lithology of the Alam El Bueib-3D, Alam El Bueib-3E and Alam El Bueib-3G was undertaken using all the logs registered through a systematic approach, and lithology was determined from logs using some types of cross plots (neutron-density and $\mathrm{M} / \mathrm{N}$ cross plot).

\section{B. Reservoir pressure analysis:}

The repeat formation tester (RFT) is an open hole $\log$ used for measuring vertical pressure distribution in a reservoir. Reservoir pressure is necessary to have knowledge of the driving mechanisms that control the behavior of fluids within reservoirs (Cole, 1969; Clark, 1969).

\section{Petrophysical evaluation:}

The well log evaluation has been achieved using Interactive Petrophysics software (IP) version 4.2. The petrophysical parameters of the Alam El-Bueib reservoirs extracted from the well log data are used to display the distribution of total thickness, shale volume, total porosity, effective porosity, water saturation, net sand or gross sand thickness, net pay thickness and hydrocarbon saturation.

\section{Results and Interpretation:}

\section{A. Determination of lithology and porosity from density-neutron crossplots:}

The density-neutron crossplots are commonly used to determine the lithology and accurately evaluate the matrix porosity of carbonate rocks. The effect of light hydrocarbons (gas) can be observed on the cross plot, where the plotted data tend to shift north-westerly from the sandstone line. Also, the effect of shale can be observed on the cross plot, where the shale effects tend to be in the southeast quadrant of the crossplot (Poupon and Leveaux, 1971).

From the density-neutron crossplot of the Alam EL-Bueib-3D reservoir of the study area (Fig. 3), it is observed that, the majority of plotted points are scattered very close to sandstone line and also in between sandstone and limestone lines with porosity ranging from $11 \%$ to $16 \%$. This indicates that the reservoir is mainly sandstone with some limestone lithology.

The density-neutron crossplot of the Alam ELBueib-3E reservoir of the study area (Fig. 4) shows that the majority of plotted points aligned on sandstone line and in between sandstone and limestone lines, with porosity ranging from $12 \%$ to $20 \%$. It indicates that the lithology is mainly sandstone with some calcareous cement.
The density-neutron crossplot of the Alam ELBueib-3G reservoir (Fig. 5) reflects that porosity ranges from $7 \%$ to $18 \%$, where the most points are scattered on and very close to sandstone line, while the rest points are plotted in between sandstone and limestone. This indicates the presence of sandstone reservoir with some limestone streaks. Some points scattered toward dolomite line are attributed to dolomitic cement. The effect of gas is observed where some points are shifted upward above sandstone line.

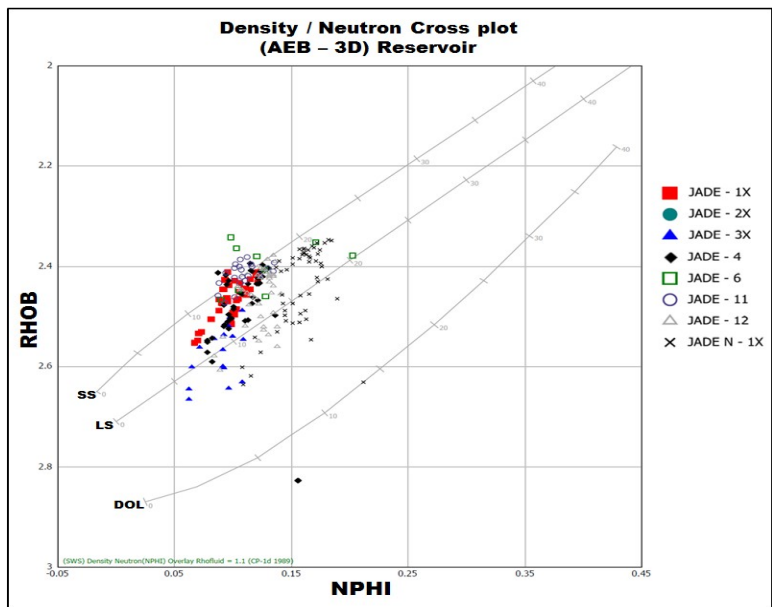

Figure (3): Density-neutron crossplot of the Alam ElBueib-3D reservoir.

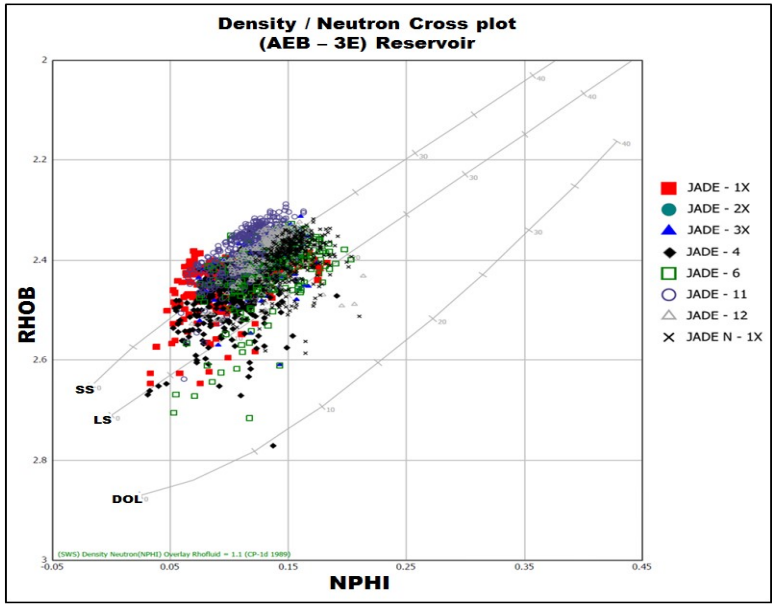

Figure (4): Density-neutron crossplot of the Alam ElBueib-3E reservoir. 


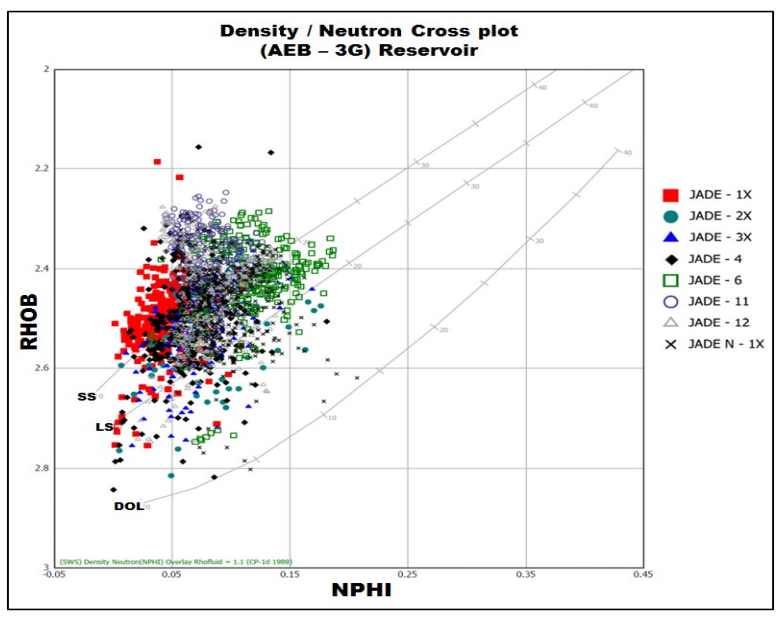

Figure (5): Density-neutron crossplot of the Alam ElBueib-3G reservoir.

\section{B. Determination of lithology from M-N crossplots:}

Lithology interpretation with neutron, density, and sonic $\operatorname{logs}$ is facilitated by the use of M-N crossplots. This plot was first introduced by Bruke et al. (1969). It combines the data of all three porosity logs to provide the lithology-dependent quantities, $\mathrm{M}$ and $\mathrm{N}$, which are essentially independent of primary porosity. Therefore a crossplot of these two quantities makes lithology characteristics be more apparent. $\mathrm{M}$ and $\mathrm{N}$ are defined as:

$\mathrm{M}=(\Delta \mathrm{tf}-\Delta \mathrm{t}) /(\rho \mathrm{b}-\rho \mathrm{bf}) \times 0.01$
$\mathrm{~N}=(\phi \mathrm{Nf}-\phi \mathrm{N}) /(\rho \mathrm{b}-\rho \mathrm{bf}) \ldots \ldots$

Where

$\Delta \mathrm{tf}$ is interval transit time of the mud fluid, $\Delta \mathrm{t}$ is sonic log reading,

$\mathrm{Pb}$ is density log reading,

$\rho b f$ is density of mud fluid,

$\phi \mathrm{Nf}$ is neutron of mud fluid,

and $\phi \mathrm{N}$ is neutron log reading.

Figure 6 shows the mineralogical composition of the Alam EL-Bueib-3D reservoir. The majority of points are scattered to fill the space between quartz and calcite regions although they tend to be close to quartz region than calcite one. This may reflect the presence of sandstone reservoir with some limestone lithology. Some points are scattered downwards due to shale effect.

Figure 7 shows that the applications of $\mathrm{M}-\mathrm{N}$ crossplot of the Alam EL-Bueib-3E reservoir. The majority of points are scattered in quartz region and in between the quartz and calcite regions. This may indicate that the lithology is mainly sandstone with some calcareous cement. Some scattered points are shifted upward due to secondary porosity effect.
Figure 8 shows the mineralogical composition of the Alam EL-Bueib-3G reservoir. The majority of points are scattered to fill the quartz region and the space in between quartz and calcite regions and they tend to be close to quartz region than calcite one. This suggests the presence of sandstone reservoir with some limestone streaks. Some points are scattered downwards due to shale effect. Also, some points are shifted upward due to secondary porosity effect.

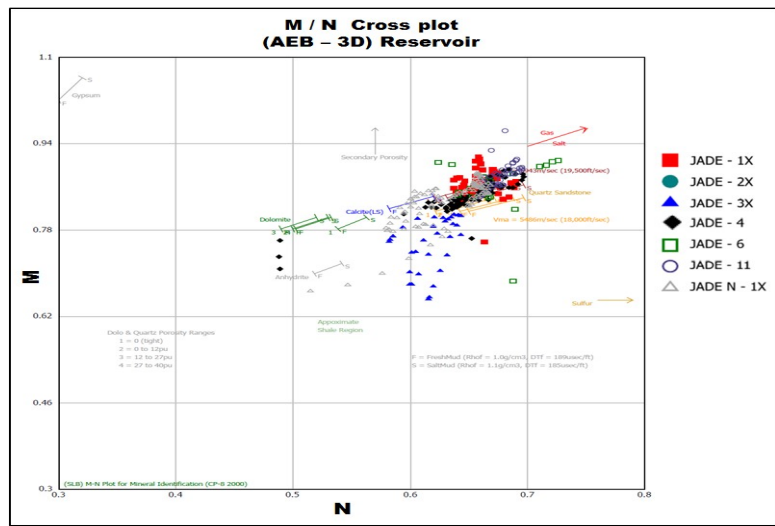

Figure (6): M - N crossplot of the Alam EL-Bueib-3D reservoir.

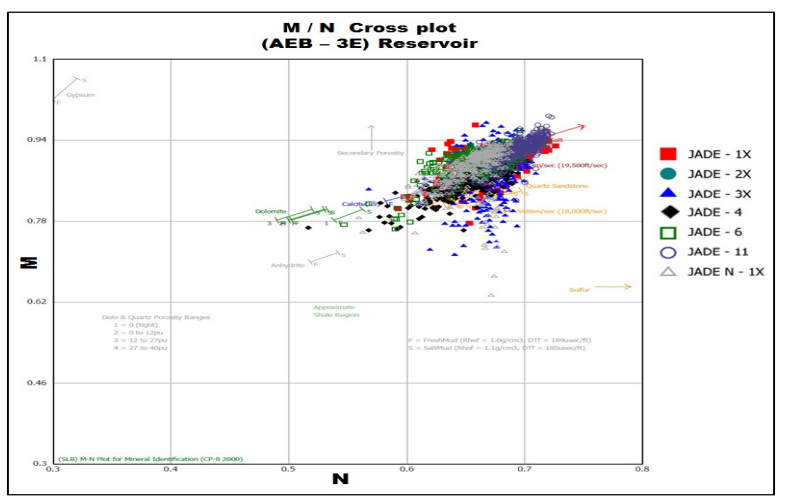

Figure (7): $M$ - N crossplot of the Alam EL-Bueib-3E reservoir.

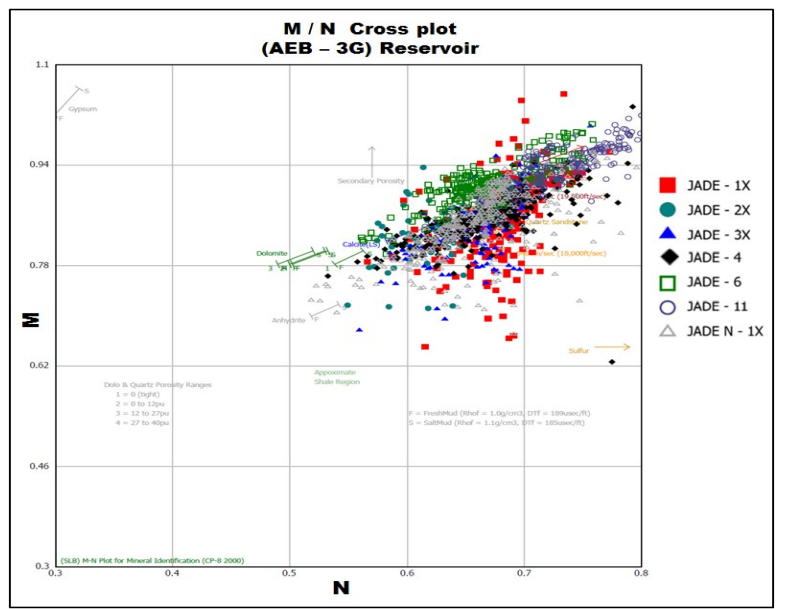

Figure (8): M - N crossplot of the Alam EL-Bueib-3G reservoir.

\section{Reservoir pressure study}


The repeat formation tester (RFT) is an open hole log used for measuring vertical pressure distribution in a reservoir. The RFT has useful applications in the field of reservoirs. Firstly in exploration wells of unproductive fields, it is known that formation pressures must conform to gravity-capillary equilibrium established over geologic times. Thus the conduct of the RFT survey and the interpretation of the data are governed by the constraint that the formation pressure data lie on straight line fluid gradients. The main objective of the testing is to delineate these gradients (water, oil and gas) and their intersections. Secondly in development wells, either partial depletion or possible water injection may already affect the observed formation pressures. Thus the new development well is used as an observation location at which the current state of the reservoir can be measured on a vertically distributed basis. A plot of formation pressure against depth can give valuable information about the reservoir, and it gives an indication of the nature of formation fluids (gas, oil, or water) as well as the position of the interfaces between different phases; gas-oil contact and oil-water contact (Stewart and Wittmann, 1979).

The analysis of pressure data of Alam EL-Bueib$3 \mathrm{D}$ reservoir is presented in figure (9) in which JADE-4, JADE-6, JADE-11, JADE-12 \& JADE N-1X wells are represented in the plot. The pressure readings in all wells are scattered and so there is no sufficient data for Alam EL-Bueib-3D to establish oil gradient and oil water contact. This is probably due to lithologic heterogeneity of Alam EL-Bueib-3D comprising sandstone with intercalation of shale and siltstone streaks. Alam ELBueib-3D reservoir, however, is considered as partial water drive due to pressure decrease from 3965 psi to 2000 psi.

The pressure analysis of Alam EL-Bueib-3E reservoir was studied in all wells. Figure (10) illustrates two oil gradients of $0.32 \mathrm{psi} / \mathrm{ft}$ and $0.33 \mathrm{psi} / \mathrm{ft}$ in JADE-4 and JADE-6 wells respectively with oil - water contact at depth $8792 \mathrm{ft}$ (TVDSS). Also, the pressure data indicates the water gradients of $0.48 \mathrm{psi} / \mathrm{ft}, 0.49 \mathrm{psi} / \mathrm{ft}$ and $0.47 \mathrm{psi} / \mathrm{ft}$ in JADE-11, JADE-12 and JADE N-1X wells respectively. The pressure data of Alam ELBueib-3E reservoir is still almost virgin, around 3980 psi and the reservoir is considered as active water drive reservoir.

Figure 11 shows the analysis of pressure data in Alam EL-Bueib-3G reservoir that were collected from five wells (JADE-4, JADE-6, JADE-11, JADE-12 \& JADE N-1X). The gas gradient of $0.12 \mathrm{psi} / \mathrm{ft}, 0.16 \mathrm{psi} / \mathrm{ft}$, $0.17 \mathrm{psi} / \mathrm{ft}, 0.11 \mathrm{psi} / \mathrm{ft}$ and $0.14 \mathrm{psi} / \mathrm{ft}$ are observed in JADE-4, JADE-6, JADE-11, JADE-12 and JADE N-1X wells respectively with original gas - water contact at $9520 \mathrm{ft}$ (TVDSS). Alam EL-Bueib-3G reservoir is considered as partial water drive due to the pressure decrease from 4320 psi to 3570 psi.

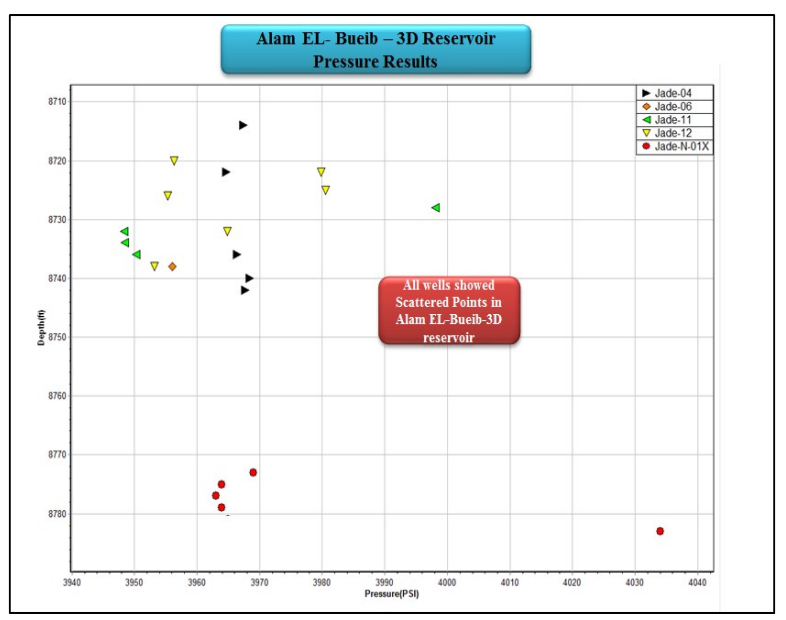

Figure (9): Alam EL-Bueib-3D reservoir pressure results.

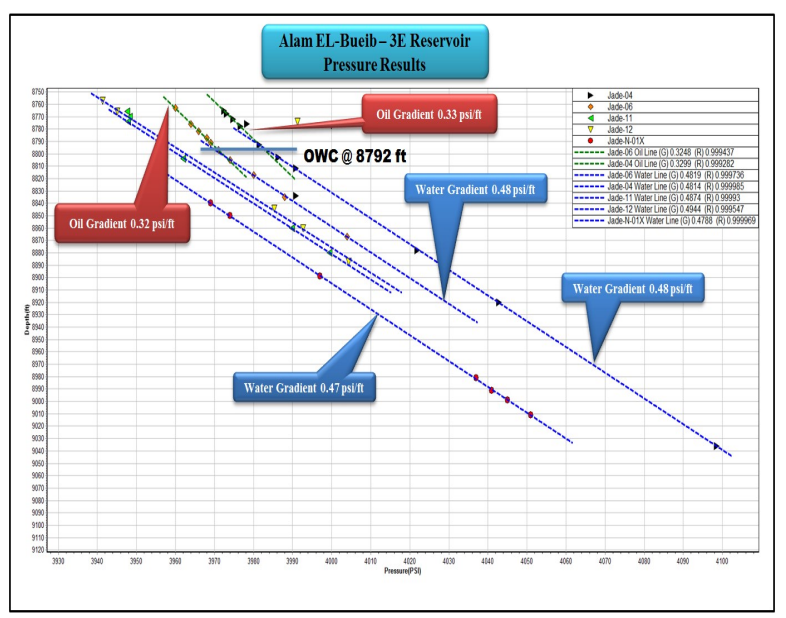

Figure (10): Alam EL-Bueib-3E reservoir pressure results.

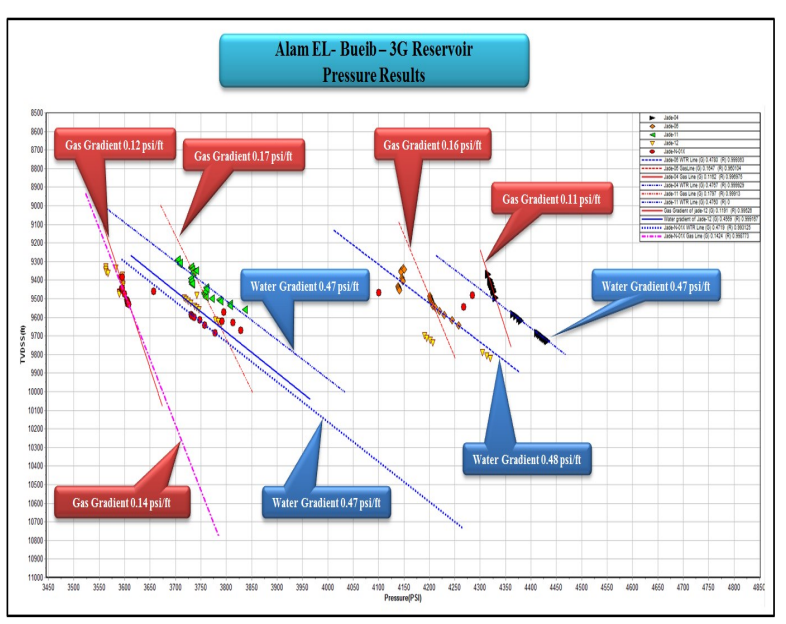

Figure (11): Alam EL-Bueib-3G reservoir pressure results. 


\section{Petrophysical evaluation}

The log- derived petrophysical parameters are presented in maps to show their general distribution throughout the Lower Cretaceous Alam EL-Bueib reservoirs.

\section{1- Alam EL-Bueib-3D Reservoir maps:}

The total thickness of Alam EL-Bueib-3D reservoir (Fig. 12a) shows that the thickness increases toward the north and southwest directions. The minimum thickness is $32 \mathrm{ft}$, at JADE-3X well and the maximum thickness is $91 \mathrm{ft}$, at JADE N-1X well.

The shale volume distribution map of Alam ELBueib-3D reservoir (Fig. 12b) shows that, it gets the lowest value of $8.1 \%$, at JADE-4 well and the greatest value is $16.6 \%$, at JADE-6 well. The shale volume content increases toward south, west and northwest directions, while it decreases in the central southern part and toward southwest and north directions.

The total porosity of Alam EL-Bueib-3D reservoir (Fig. 12c) attains the lowest value of $11.7 \%$, at JADE$3 \mathrm{X}$ well, while the highest value is $17.6 \%$, at JADE N$1 \mathrm{X}$ well. The total porosity increases toward the central southern and northern parts and southwest direction of the study area, and decreases toward the north, west and northwest directions.

The effective porosity increases toward the central southern and northern parts and southwest direction. Meanwhile it decreases at the west, north and northwest directions. The minimum effective porosity (Fig. 12d) value of $8.7 \%$, is noticed at JADE-3X well, while the maximum effective porosity value is $14.6 \%$, at JADE N-1X well.

The water saturation of Alam EL-Bueib-3D reservoir increases to the south and northwest directions and decreases in the central southern and northern parts and toward southwest direction. The water saturation increases to reach $64.8 \%$, at JADE-3X well, and attains the lowest value of $25.8 \%$, at JADE-4 well (Fig. 12e). Figure (12f) represents the gross sand map of Alam ELBueib-3D reservoir in JADE field. It reaches the maximum value of $25.5 \mathrm{ft}$ at JADE-1X well and the minimum value of $3 \mathrm{ft}$ at JADE- $3 \mathrm{X}$ well. The gross sand increases in the central southern and northern parts.

The net pay thickness distribution map (Fig. 12g) reveals that the net pay thickness ranges from zero at JADE-2X and JADE-3X wells to $19 \mathrm{ft}$ at JADE-1X well. The thickness of net pay increases in the central southern and northern parts and toward southwest direction of the study area. The hydrocarbon saturation map of Alam EL-Bueib-3D reservoir (Fig. 12h) shows that the hydrocarbon saturation increases in the central southern and northern parts and toward southwest direction. It decreases toward south, northwest and in the central part of the study area. The hydrocarbon saturation attains a maximum value of $74.2 \%$, at JADE-4 well and the minimum value is $35.2 \%$, at JADE-3X well.

\section{2- Alam EL-Bueib-3E Reservoir maps}

The total thickness of Alam EL-Bueib-3E reservoir (Fig. 13a) shows that the thickness increases in the central part and toward northwest direction of the study area. The Alam EL-Bueib-3E unit has lowest thickness of $399 \mathrm{ft}$, at JADE N-1X well and the maximum thickness is $535.5 \mathrm{ft}$, at JADE-2X well.

The shale volume distribution map (Fig. 13b) displays that the shale volume attains the low value of 4 $\%$, at JADE- 4 well, while the high value is $6.3 \%$, at JADE N-1X well. The shale volume increases toward the north and south directions, while it decreases in the central southern part and towards southwest direction of the study area.

The total porosity distribution map (Fig. 13c) shows that the total porosity has its lowest value of $14.1 \%$, at JADE- 4 well, and its highest value is $17.1 \%$, at JADE-6 well. The total porosity increases toward west direction and in the central southern part of the study area, while it decreases toward south and north directions. The effective porosity distribution map (Fig. 13d), shows that the effective porosity attains $12.5 \%$, at JADE-4 well, while it reaches $15.7 \%$, at JADE- 6 well. The effective porosity increases in the central southern part and toward west direction, while it decreases toward north and south direction.

The water saturation distribution map (Fig. 13e) reflects that the water saturation decreases toward the central southern part of the study area. The water saturation increases reaching maximum value of $98.8 \%$, at JADE-3X well and decreases till reach minimum value of $27.3 \%$, at JADE-6 well.

The gross sand distribution map (Fig. 13f) reflects that the net sand increases to reach its highest value of $432 \mathrm{ft}$, at JADE-2X well and it decreases to $309 \mathrm{ft}$ at JADE N-1X well. The gross sand increases in the central southern part and towards north, northwest and west directions while it decreases in the central part and toward south direction of the study area.

The net pay thickness distribution map (Fig. 13g) reveals that the net pay thickness attain zero at JADE$1 \mathrm{X}, 2 \mathrm{X}, 3 \mathrm{X}, 11,12$ and N-1X wells. The net pay attains its highest value of $38.5 \mathrm{ft}$, at JADE- 6 well and it increases toward the central southern part of the study area.

The hydrocarbon saturation gets its high value of $72.7 \%$ at JADE-6 well and the low value is $1.2 \%$, at JADE-3X well. The hydrocarbon saturation increases toward the central southern part of the study area (Fig. 13h).

\section{3- Alam EL-Bueib-3G Reservoir maps}

The total thickness of Alam EL-Bueib-3G reservoir (Fig. 14a) shows that the thickness increases toward the southwest and northwest directions, while it decreases in the middle part of the study area. The minimum thickness is $297 \mathrm{ft}$ at JADE-2X well and the maximum thickness is $743 \mathrm{ft}$ at JADE-1X well. 
The shale volume distribution map of Alam ELBueib-3G reservoir (Fig. 14b) shows that, it gets the lowest value of $3.4 \%$, at JADE-12 well and the greatest value of $9.6 \%$ at JADE-2X well. The shale volume increases toward the south and northwest directions and in the central part of the study area, while it decreases in the central southern part of the study area.

The total porosity of Alam EL-Bueib-3G reservoir attains the lowest value of $9.8 \%$ at JADE-2X well, and the highest value of $15.9 \%$ at JADE- 6 well. The total porosity increases in the central southern part and toward north direction of the study area, and decreases toward the south and northwest directions and in the central part of the study area (Fig. 14c). The effective porosity value increases in the central southern part and toward north direction of the study area. Meanwhile it decreases toward the south and northwest directions and in the central part of the study area. The minimum effective porosity value is $7.7 \%$ at JADE-2X well, and the maximum effective porosity value is $14.7 \%$ at JADE-6 well (Fig. 14d).

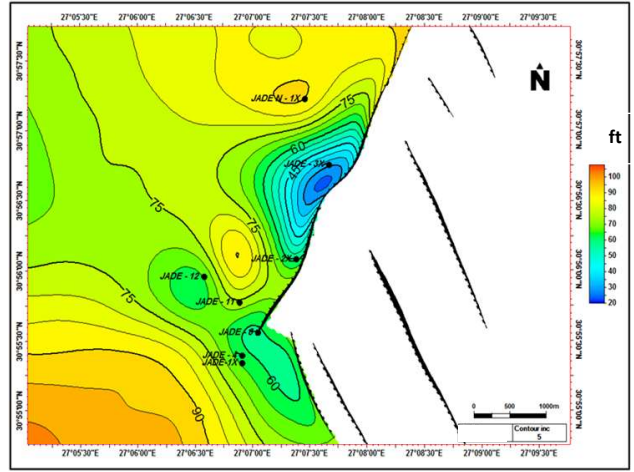

(a)

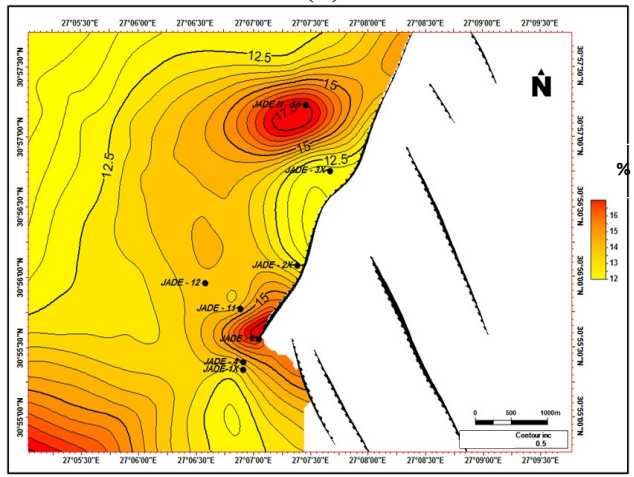

(c)
The water saturation of Alam EL-Bueib-3G reservoir decreases toward the central southern and northern parts of the study area. The water saturation increases to reach $90.1 \%$ at JADE-3X well, and the lowest value of $13.5 \%$ at JADE-11 well (Fig. 14e).

Figure (14f) represents the gross sand map of Alam EL-Bueib-3G reservoir in JADE field. It reaches the maximum value of $523 \mathrm{ft}$ at JADE-12 well and the minimum value of $106.5 \mathrm{ft}$ at JADE-2X well. The gross sand increases in the central southern part and towards north and southwest directions. The net pay thickness distribution map (Fig. 14g) reveals that the net pay thickness ranges from zero at JADE-2X and JADE-3X wells to $156 \mathrm{ft}$ at JADE-11 well. The net pay thickness increases in the central southern and northern parts of the study area.

The hydrocarbon saturation map of Alam ELBueib-3G reservoir (Fig. 14h) shows that the hydrocarbon saturation increases in the central southern part and toward north direction. It decreases toward south and west. directions of the study area

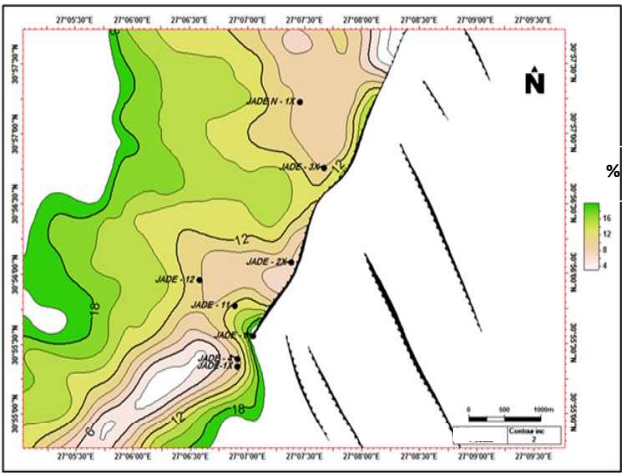

(b)

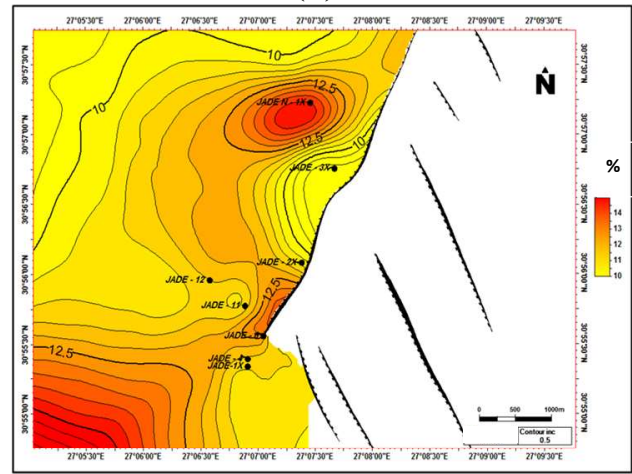

(d) 


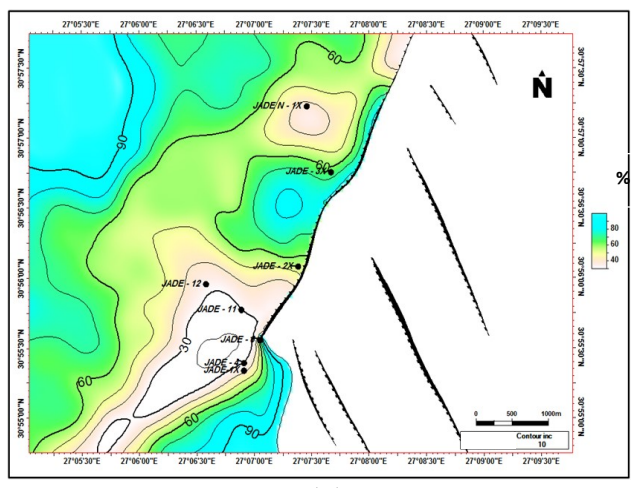

(e)

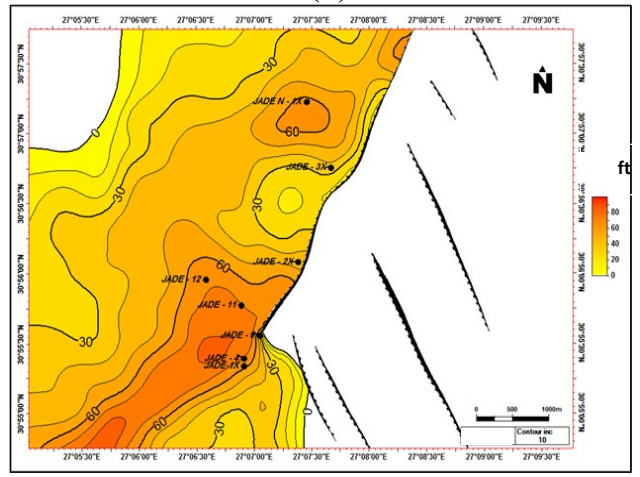

$(\mathrm{g})$

Figure (12): Reservoir parameters of Alam EL-Bueib-3D reservoir, Jade field.

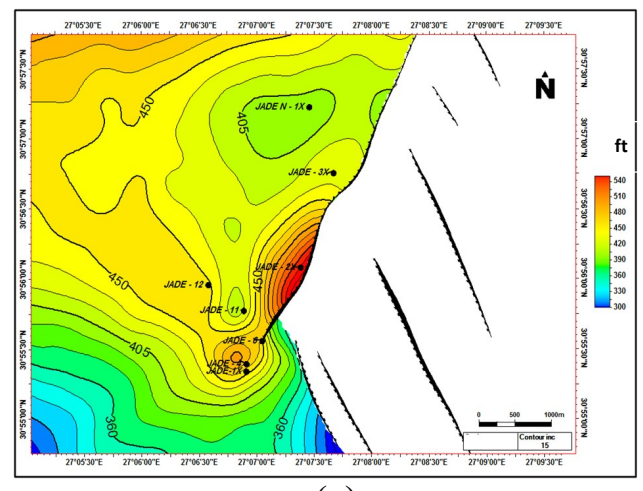

(a)

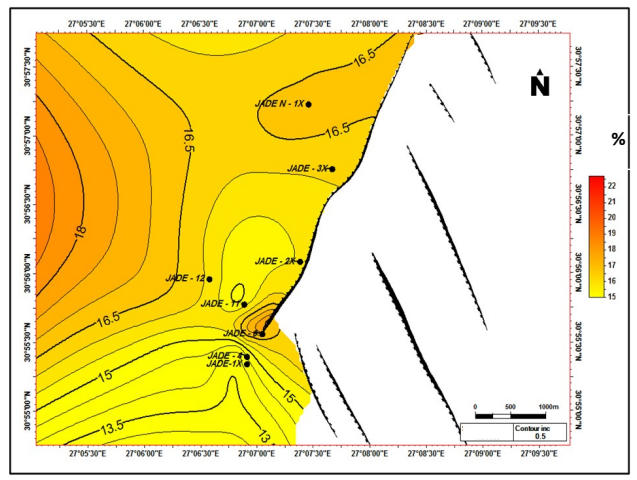

(c)

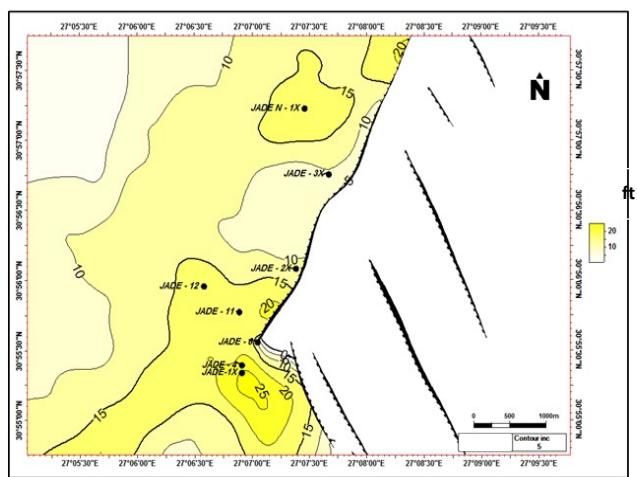

(f)

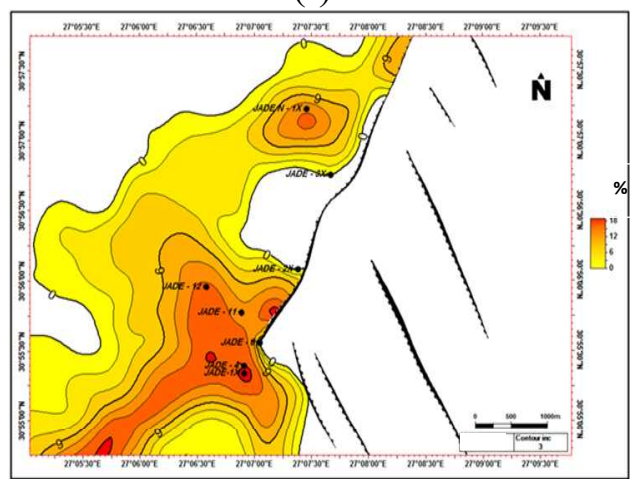

(h)

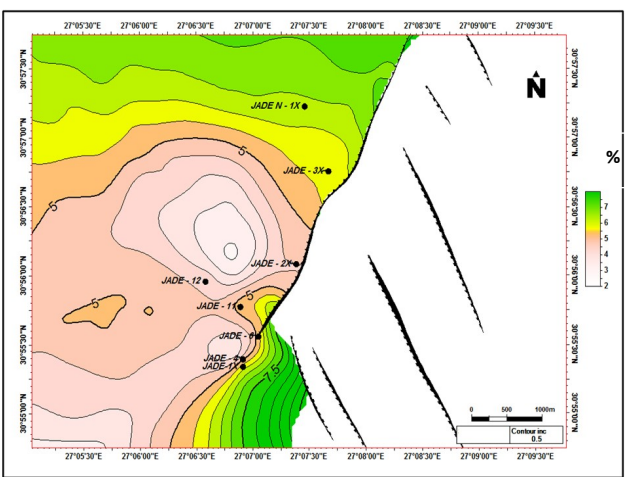

(b)

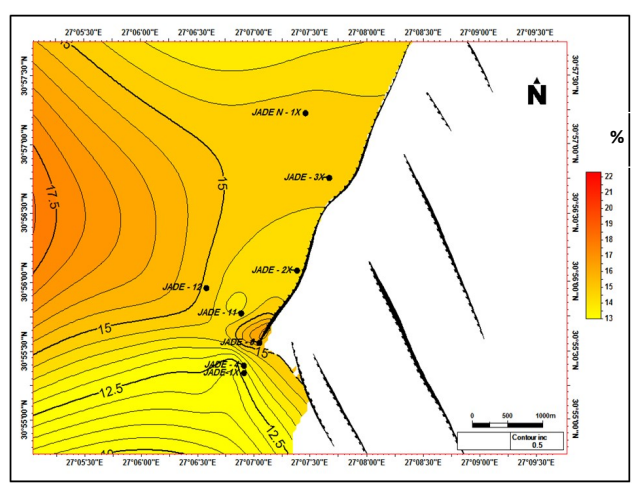

(d) 


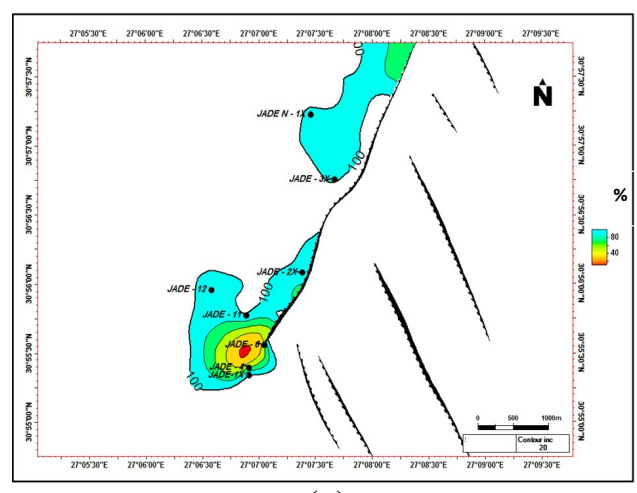

(e)

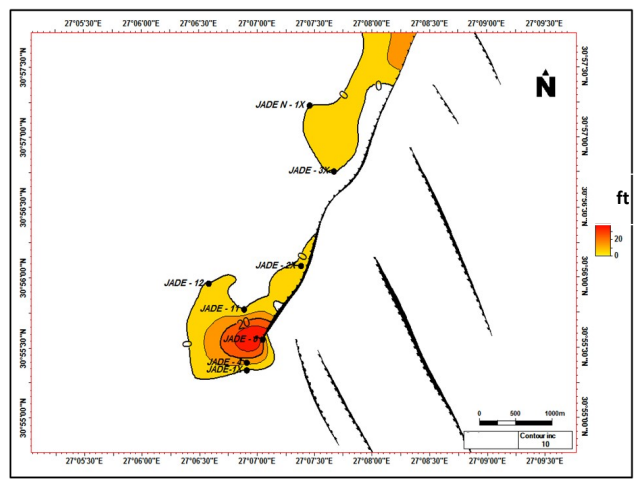

(g)

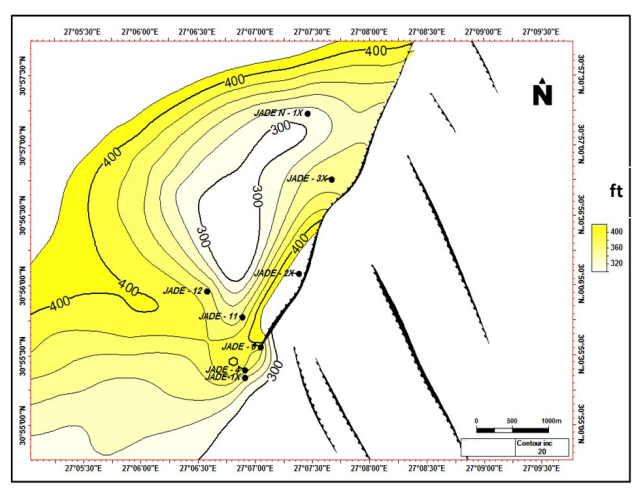

(f)

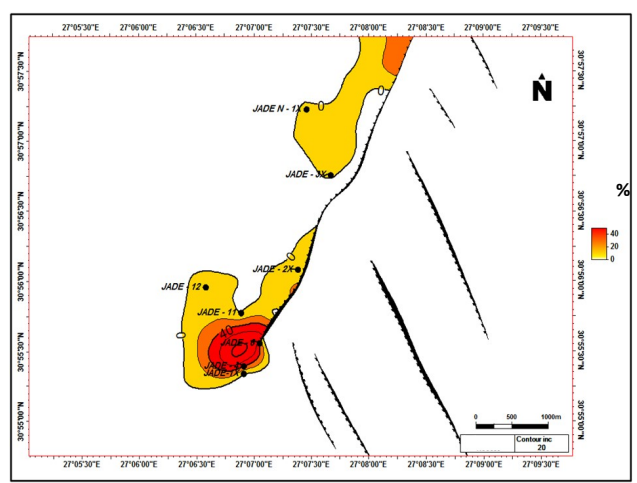

(h)

Figure (13): Reservoir parameters of Alam EL-Bueib-3E reservoir, Jade field.

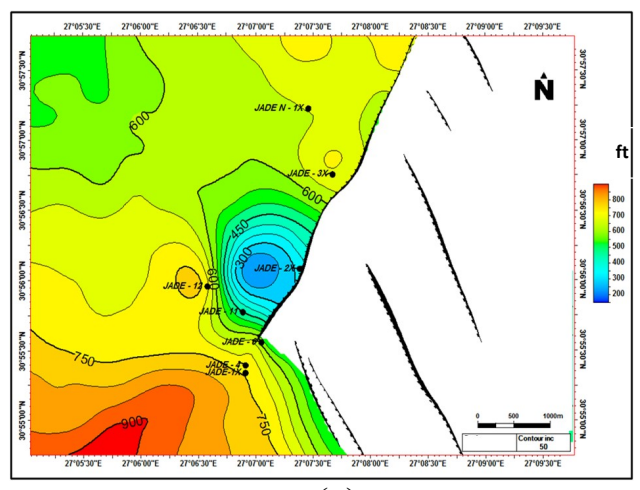

(a)

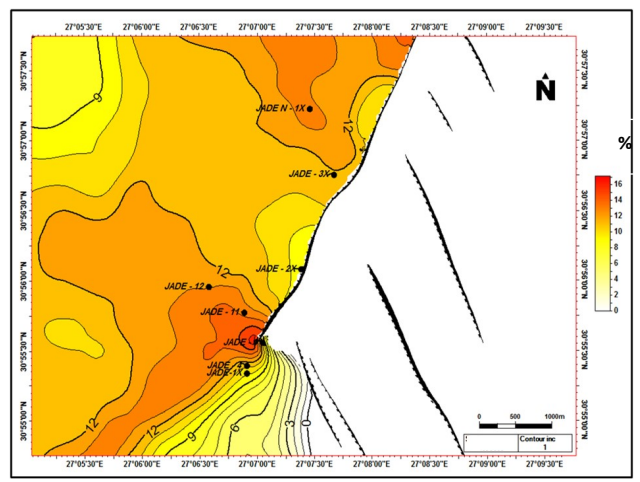

(c)

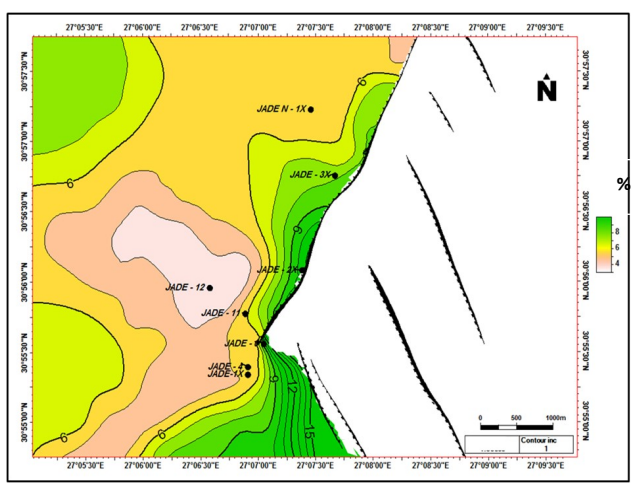

(b)

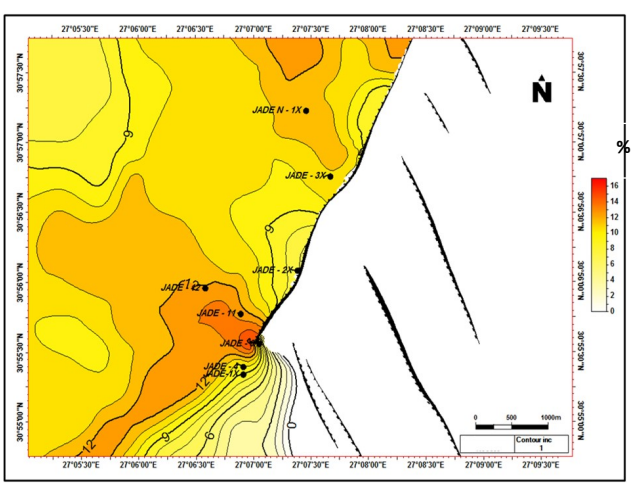

(d) 


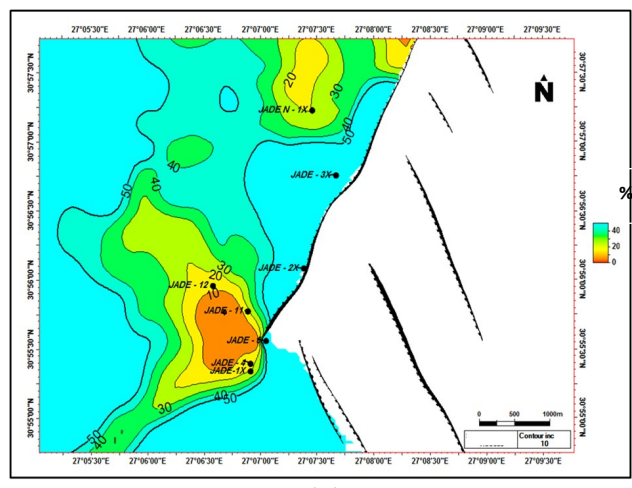

(e)

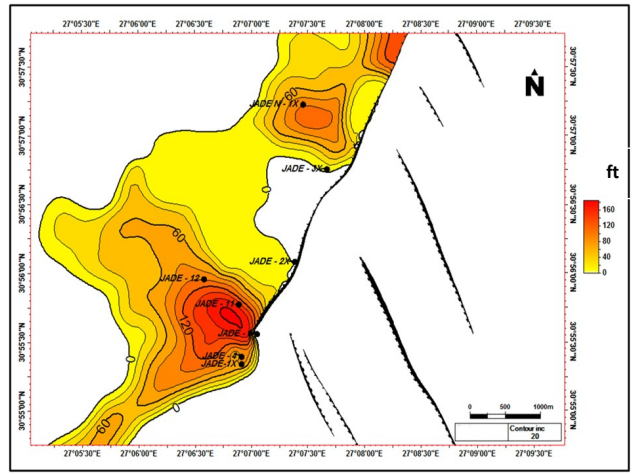

(g)

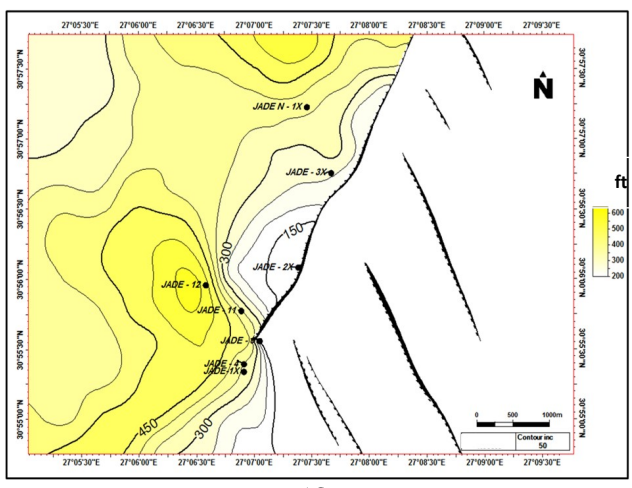

(f)

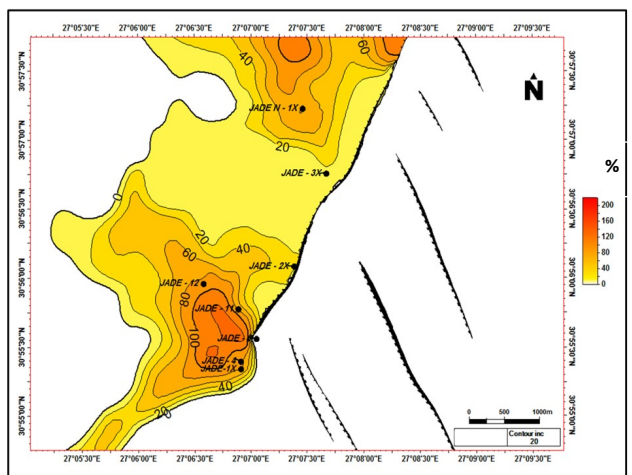

(h)

Figure (14): Reservoir parameters of Alam EL-Bueib-3G reservoir, Jade field.

. Hydrocarbon saturation attains a maximum value of $86.5 \%$ at JADE- 11 well and the minimum value of 9.9 $\%$ at JADE-3X well.

\section{Summary and Conclusion:}

Careful analysis of petrophysical parameters from eight wells distributed in Jade field reveals the presence of three good quality reservoirs in the Alam EL-Bueib Formation, namely the Alam EL-Bueib-3D, 3E and 3G.

The density-neutron and M-N cross-plots of the Alam EL-Bueib Formation indicate the presence of sandstone with some calcareous cement in all studied wells. In additions the effect of gas appears in shifting some points up-ward the diagrams.

The analysis of reservoir pressure data shows that Alam EL-Bueib-3D is characterized by partial drive mechanism, as indicated by decrease of pressure from 3965 to 2000 psi with production. The analysis of reservoir pressure data shows that Alam EL-Bueib -3E is considered as active water drive reservoir and the probable oil water contact at depth (8792 feet), while Alam EL-Bueib-3G reservoir is considered as partial water drive due to pressure decrease from 4320 to 3570 psi, also gas fluid is observed in the most wells.

The results of well log analysis are presented in the form of maps. The iso-parametric maps show the lateral variation of petrophysical parameters and they are useful to expect new places for drilling more productive wells.

The maps of petrophysical parameters of the Alam EL-Bueib-3D reservoir revealed that the central southern and northern parts of the study area are attractive locations to drill another productive wells due to increase in effective porosity, net pay thickness and hydrocarbon saturation. The Alam EL-Bueib-3E isoparametric maps show that the central southern part of the study area is the most favorable part for hydrocarbon accumulation and production as the effective porosity, 
net pay thickness and hydrocarbon saturation as well as the movable hydrocarbon saturation increases toward this part of the study area. The horizontal distribution of Alam EL-Bueib-3G petrophysical parameters show that the expected locations to develop this reservoir are toward the central southern and northern parts of the study area.

In conclusion, it can be stated that the Alam ElBueib Formation contains excellent reservoir zones with variable lithological composition that reflects different local depositional environment. Also Alam EL-Bueib units have a good porosity values them make favorable for oil and gas accumulation. The present study has proved that there is a good opportunity to drill more wells to develop the productivity from Jade field, particularly toward the central southern and northern parts of the study area.

\section{References:}

Amin, M.S., 1961: Subsurface features and oil prospects of the Western Desert. Egypt: 3rd Arab Petrol. Cong., Alexandria.

Bruke, J.A., Campbell, R.L. and Schmidt, A.W., 1969: The litho-porosity crossplot. The log analyst (SPWLA), 10 (6).

Clark, N., 1969: Elements of Petroleum Reservoirs. SPE, Dallas.

Cole, F., 1969: Reservoir Engineering Manual. Gulf Publishing Co., Houston.

E1 Gezeery, N.H., Mohsen, S.M. and Farid, M.I., 1972: Sedimentary basins of Egypt and their petroleum prospects. 8th Arab Petrol. Cong., Algiers, 1-15.

El-khadragy, A.A. and Sharaf, M., 1994: Inferring the basement structure of northwestern Desert, using potential field data. Bull. Fac. Sci., Zagazig Univ., 16(2): 92-110.
El-khadragy, A.A., Saad, M.H. and Azab, A., 2010: Crustal modeling of south Sitra area, north Western Desert, Egypt using Bouguer gravity data. Journal of Applied Science Research, 61(1): 22-27.

Hantar, G., 1990: North Western Desert. In: Said, R. (Eds.). The geology of Egypt. A. A. Balkema, Rotterdam, Netherlands. pp. 293-319.

Kostandi, A.B., 1963: Eocene facies maps and tectonic interpretation in the Western Desert, Egypt. Revue de 1' Institute Francais.

Poupon, A. and Leveaux, J., 1971: Evaluation of water saturation in shaly parts of northern Egypt. AAPG., 60 (1).

Rebortson Research International Limited (RRI), 1982: Petroleum potential evaluation of the Western Desert, Egypt. Unpublished report prepared for EGPC (8 Volumes).

Said, R., 1962: The geology of Egypt. Elsevier Publ. Co., Amsterdam, Oxford and New York, 277 p.

Schlumberger, 1984: Well evaluation conference, Egypt. Geology of Egypt, pp. 1-64.

Schlumberger, 1995: Well Evaluation Conference, Egypt. Schlumberger Technical Editing Services, Chester. pp. 58-66.

Shalaby, M.R., El Awady, M.M., Abdel Hameed, A.T. and Abu shady, A.N., 2000: Structural setting and sedimentary environments using dipmeter analysis of some Jurassic reservoirs, North Western Desert, Egypt, 5th International Conf., Geology of the Arab World (GAW-5), Cairo Univ., Egypt, pp. 217-220.

Shata, A.A., 1953: A new light on the structural development of the Western Desert of Egypt. Inst. Desert Bull. Cairo, Egypt, 3 (1): 101-106. 
Shukri, N.M., 1954: Remarks on the geological structure of Egypt. EGS Bull. Cairo, Egypt, 27: 65-82.

Sigaev N.A., 1959: The main tectonic features of Egypt, an explanatory note to the tectonic map of Egypt. Publ in 1967, Ann. Geol. Surv., Cairo, Egypt, No. $39,26 \mathrm{p}$.

Stewart, G. and Wittmann, M.J., 1979: Interpretation of pressure response of the repeat formation tester, SPE, fall meetings in Las Vegas, 8362 p.

Sultan, N. and Abd El-Halim, M.A., 1988: Tectonic framework northern Western Desert, Egypt and its effect on hydrocarbon accumulations. 9th Expl. Conf., EGPC, Cairo, Egypt, 31 p.
Zein El Din, M.Y., Abd El-Gawad, E.A., El Shayb, H.M. and Haddad, I.A., 2001: Geological studies and hydrocarbon potentialities of the Mesozoic rocks in Ras Kanayis onshore area, North Western Desert, Egypt.

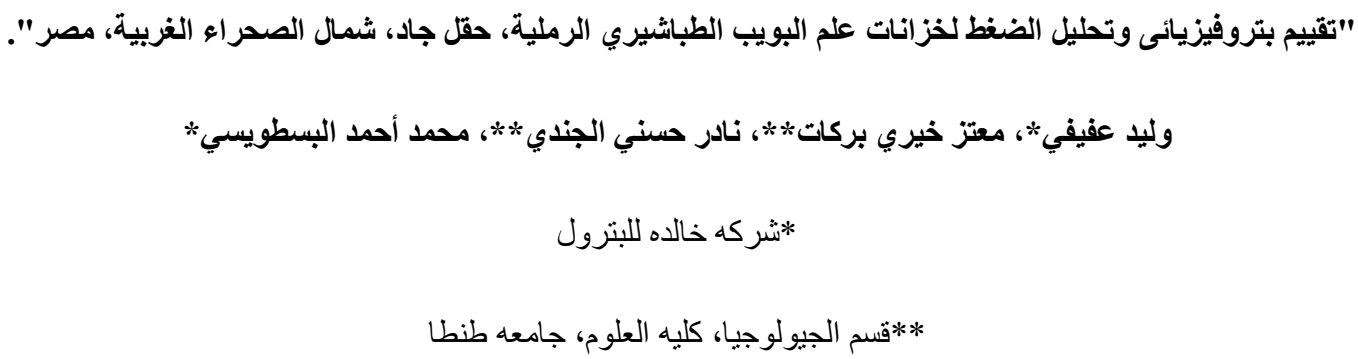


ويتضـح من الخر ائط البتروفيزيائيسة أن خزان العضو (3D) من منكون علم البويب تتحسن معاملاته البتروفيزيائية فى منتصف منطقة الدراسـه الثمالى و الجنوبى نتيجه لزيادة المساميه الكليه والفعليه ودرجة التتبع الهيدروكربونى بالإضـافه الى أن صسافى السمك المنتج للزيت يزداد فى هذا الإتجاه. كما يتضح من الخر ائط أن خزان العضو (3E) من منكون علم البويب تتحسن معاملاته البتروفيزيائية فى إتجاه منتصف الدر اسـة الجنوبى نتيجه لزيادة المساميه الكليه و الفعليه ودرجة التشبع الهيدروكربونى بالإضافه إلى أن صافى السمك المنتج للزيت يزداد فى هذا الإتجاه. أمسا بالنسبة لخزان العضو (3G) من متكون علم البويب فتتحسن المعاملات البتروفيزيائية السالف ذكر ها فى إتجاه منتصف منطقة الدر اسه الثمالى و الجنوبى. 